\title{
A construção de Palmas no final da década de 80. Uma concialiação ou um rompimento dos pactos de poder da elite agrária?
}

The construction of Palmas in the late 1980s: conciliation or rupture of the power agreement among the landowning elite?

Elisen Pereira de Brito - Bacharel e licenciado em Geografia pela Universidade Federal do Tocantins; Mestre em Geografia pela Universidade Federal da Grande Dourados; Pesquisador vinculado ao NURBA/UFT. Atualmente, é professor na Universidade Federal do Tocantins. E-mail: pereiradebrito@gmail.com

\section{Resumo}

Esta pesquisa faz parte de uma análise sobre a formação socioespacial do estado do Tocantins, objetivando identificar pontos que respaldam a criação e consolidação de Palmas, por meio de uma leitura dos pactos da dualidade econômica brasileira. Para o autor, houve duas condições determinantes da criação de Palmas, de um lado, uma cidade resultante de uma conciliação dos pactos de poder da oligarquia agrária e, sobre outra perspectiva, uma cidade que representou o rompimento com as oligarquias a partir do momento que objetivou uma cidade com amplo mercado produtor e consumidor de serviços e produtos industrializados, diferenciando dos rumos econômicos da elite agrária para o estado.

\begin{abstract}
This study is an analysis on the formation socio-spacial of the state of the Tocantins it has like objective identify points what they support the creation and consolidation of Palmas, through a reading of the pacts of the economical Brazilian duality. For the author, there were two determinative conditions of the creation of Palmas, of a side, a resultant city of a conciliation of the pacts of power of the agrarian oligarchy and, on another perspective, a city that represented the breakage with the oligarchies, presenting a city with great producing market and consumer market, of services and industrialized products different from the economical objectives of the agrarian elite for the state.
\end{abstract}

\section{Palavras-chave}

Dualidade da Economia. Formação Socioespacial. Criação de Palmas

\section{Keywords}

Duality of the Economy. Socio-Spacial Formation. Creation of the Palmas 


\section{INTRODUÇÃO}

Ao tratar sobre a cidade de Palmas, buscou-se analisar um conjunto de fatores que desenhassem a estratégia da criação da cidade.

Propor-se nortear a pesquisa a partir das orientações estabelecidas por Ignácio Rangel $(1981,2005)$ sobre a formação socioespacial do Brasil. Como contribuição à leitura regional, as pesquisas de Valverde e Dias (1967), Furtado (2005) foram de fundamental importância para o trabalho.

Com uma análise sobre a formação socioespacial do Tocantins, duas questões sobressaíram direcionando a investigação: Palmas foi uma cidade do rompimento com as elites agrárias ou, Palmas foi uma concretização dos laços de poder desta elite? Neste caso uma cidade da conciliação do sócio maior com o sócio menor.

\section{UMA LEITURA EM IGNÁCIO RANGEL}

Rangel (1981 e 2005) entendeu o processo histórico da economia brasileira como constituído por fases sucessivas de dualidades. Para cada uma dessas fases, comportavam-se formações econômicas dominantes, tendo uma situada no polo externo e outra, no polo interno da economia. Estas duas formações básicas da economia, controlada por leis próprias se estabelecem no território por um permanente conflito entre si por ser dominantes em seus espaços.

Neste sentido, ela é dual e simétrica a economia mundial, porém, segundo Pereira (1993), a história do Brasil não refletiu fielmente a história europeia, isso se deu porque a evolução não foi autônoma e nem formada exclusivamente pelas suas forças internas. Isso implica dizer que, a coexistência dual de relações históricas no país é defasada em relação a existente na Europa.

Formada em sua estrutura por dois polos: um polo externo e um polo interno,

essa estrutura (uma formação agrupando quatro modos elementares de produção, distribuídos dois a dois, para formar os pólos interno e externo respectivamente) manter-se-ia até nossos dias, embora mudando seus elementos constitutivos (seus lados) e a maneira como estes se combinam para formar os dois pólos (RANGEL, 2005, p.660).

Delimitando no tempo a dualidade da economia do Brasil, colocou-se um marco a vinda da família real portuguesa, como propriamente o edifício da dualidade econômica brasileira tal como, mutatis mutandis. Este processo foi decorrente da interpretação de Rangel (2005), de que as formações matrizes metropolitanas da Europa Ocidental eram duais. No período do descobrimento do Brasil (1500), a estrutura econômica européia estava alicerçada sobre o modo feudal de produção, mas havia modo de produção capitalista baseado sobre o mercantilismo. No caso brasileiro, a Abertura dos Portos (1808) e a Independência do País, rompeu com o escravismo pré-capitalista que até então era o modo de produção principal do país. Com este rompimento na estrutura da produção tornou-se possível analisar a dualidade da economia no país.

Para Rangel (2005), a comunidade primitiva foi desorganizada a partir da exploração de sua força de trabalho nos moldes escravistas. O nativo foi caçado e inserido a um regime de escravidão. No entanto, mesmo o Brasil nascendo sobre as relações do capitalismo mercantil, este modo de produção ficou restrito ao seu polo externo. A autonomia brasileira de poder escolher sobre quais alicerces apoiar a economia, tendo como base uma potência mundial, levou a afirmar que a formação dual brasileira ao confrontar-se com a expansão de suas forças produtiva reagiu como as demais formações sociais, mudando o seu modo de produção para outro que estavam em estágios mais inovados tecnologicamente.

A formação dual da sociedade brasileira reflete que o poder político é exercido sempre por duas forças majoritárias. Enquanto uma força ocupa o poder, surge uma nova força para substituí-la no poder. São organizações de classes dirigente, simultaneamente conflitantes e solidárias, daí pode-se falar de pacto de poder.

O lado externo do polo externo situa-se fora do país, é o modo de produção ativo nos centros mundiais em que a economia está ligada. Dessa forma, sobram três lados que disputam as duas representações de classe dirigente no país. O polo interno do lado interno está submetido ao interesse dos lados internos e externos da sociedade.

Ora, o pólo interno está subposto à apenas uma classe e não a duas, e seu protótipo foi a classe dos vassalos-senhores de escravos, isto é feudais, em suas relações externas (com a Coroa) e escravistas no campo das relações internas. Simetricamente a fazenda era uma feudo-vila (nos sentidos medieval e romano desses termos, respectivamente). Assim, os interesses correspondentes aos dois modos elementares de produção, dialeticamente unidos no pólo interno, manifestam-se como ordens diferentes e contraditórias de interesses (potencialmente inconciliáveis) do mesmo grupo de pessoas, isto é, voltando ao nosso protótipo de classe (híbrida) dos vassalos-senhores de escravos, a mesma classe vê-se sacudida entre os interesses da fazenda, enquanto feudo. (RANGEL, 1981, p. 15)

Em contrapartida, a classe representante do polo externo sempre terá de conciliar diferentes ordens e contraditórias, que vêm dos interesses dos modos de 
produção. Quando isso não é mais possível, há um rompimento com todas elas, menos a escolhida para a conciliação. Esta nova classe formada troca-se de modo de produção, sendo este um novo e avançado em comparação com o anterior (RANGEL, 1981).

A dualidade é explicada pela existência de dois polos e, é sobre os polos que se define os lados e consequentemente os sócios. No "pólo interno situamse, internamente, as relações de produção dominantes e a correspondente a classe dominante" (PEREIRA, 1993), chamada de sócio maior. No polo externo, situam-se as relações de produção emergentes, chamada de sócio menor. Mas, não necessariamente os sócios estão em apenas um polo, varia de acordo com a organização da economia.

Esta classificação pode ser vista conforme a estrutura política da sociedade dual brasileira:

Quadro 1. O sócio maior e o sócio menor na economia brasileira

\begin{tabular}{|l|c|c|c|c|}
\hline Lado Interno & $\mathbf{1}^{\mathbf{a}}$ dualidade & $\mathbf{2}^{\mathbf{a}}$ dualidade & $\mathbf{3}^{\mathbf{a}}$ dualidade & $\mathbf{4}^{\mathbf{a}}$ dualidade \\
& $\begin{array}{c}\text { Sócio Maior: } \\
\text { Barões- } \\
\text { senhores de } \\
\text { escravos }\end{array}$ & $\begin{array}{c}\text { Sócio Menor: } \\
\text { Fazendeiros e } \\
\text { comerciantes }\end{array}$ & $\begin{array}{c}\text { Sócio Maior: } \\
\text { Fazendeiros e } \\
\text { comerciantes }\end{array}$ & $\begin{array}{c}\text { Sócio Menor: } \\
\text { Nova burguesia } \\
\text { rural }\end{array}$ \\
\hline Lado Externo & $\begin{array}{c}\text { Sócio Menor: } \\
\text { Classe dos } \\
\text { Comerciantes }\end{array}$ & $\begin{array}{c}\text { Sócio Maior: } \\
\text { Burguesia } \\
\text { Comerciante }\end{array}$ & $\begin{array}{c}\text { Sócio Menor: } \\
\text { Burguesia } \\
\text { Industrial }\end{array}$ & $\begin{array}{c}\text { Sócio Maior: } \\
\text { Burguesia } \\
\text { Industrial }\end{array}$ \\
\hline
\end{tabular}

Fonte: Rangel (2005) organizado pelo autor.

Esta mudança do pacto de poder forma duas forças políticas: uma conservadora e outra, progressista, formando os lados internos. O grupo dissidente que saiu das representações conservadoras, não enfrentará oposição em primeira instância, até porque, a classe representante do lado interno do polo externo não estará em crise.

Em contrapartida, a classe conservadora tem possibilidade de disputar o poder na classe em crise, negociando um novo pacto de poder que formará uma nova classe, uma nova dualidade. Na nova dualidade, a classe do polo não renovado compartilhará o poder com a classe do polo renovado, que de dissidente passa a ser uma classe em formação. Rangel (1981) afirma que,

a primeira é uma classe [pólo não renovado] em plena maturidade, consciente de seus interesses (uma classe em si e para si), traz consigo preciosa experiência de uso do poder, ao passo que a segunda [pólo renovado] é politicamente inexperiente (uma classe em si, apenas), não obstante ser portadora de grande dinamismo. Não deve espantar, pois, que em cada dualidade historicamente formada o poder seja exercido hegemonicamente pela primeira, a mais velha, desfrutando a outra de plena liberdade para fazer prova do seu dinamismo, em tudo o que não conflite com os interesses da classe hegemônica (RANGEL, 1981, p. 17).

O capitalismo no Brasil nasceu nos moldes industriais, mesmo tendo o capitalismo mercantil como ressurgente, que permaneceu por um longo período como externo à formação social nacional. Sua forma de implantação rompeu com os padrões europeus e orientou-se a uma formação mais avançada e dinâmica do mundo àquele tempo, no estilo do capitalismo industrial inglês.

O crescimento das forças produtivas proporcionou mudanças no modo de produção nacional, escalonando-a para uma produção superior. Este processo obedeceu a certas leis específicas:

Primeira lei: quando se cumpre as precondições para a passagem a um estágio superior - basicamente, quando as forças produtivas da sociedade crescem, entrando em conflito com as relações de produção existentes, consubstanciadas na dualidade básica -, esta muda, como todas as formações sociais em tais casos, mas o faz apenas por um dos seus 'pólos', guardando o outro sua estrutura e integrando-se na nova dualidade, correspondendo ao estágio imediatamente superior do desenvolvimento.

Segunda lei: alternadamente, mudam o pólo interno e o externo.

Terceira lei: o pólo muda pelo processo de passar para o lado interno o modo de produção já presente no seu lado externo.

Quarta lei: consequentemente, o lado externo do pólo em mudança muda, também, passando a adotar instituições características de um modo de produção mais avançado, que comporá nova união dialética (de contrários) com o lado interno recém-criado.

Quinta lei: como formação periférica que é, as mudanças da dualidade brasileira são provocadas por mudanças no comportamento do centro dinâmico em torno do qual gravita nossa economia, particularmente no que concerne ao quantum e aos termos de intercâmbio do seu comércio conosco (RANGEL, 2005, p.662).

Neste mesmo norte, pode-se dividir a estrutura política da sociedade dual, ou seja, "o Estado brasileiro resulta da aliança de apenas duas classes dirigentes, associadas num pacto de poder implícito, que só muda com a dualidade, sejam quais forem os estamentos pelos quais as duas classes dirigentes se façam representar" (RANGEL, 2005, p.665). Mas, um dos lados representa interesses externo ao Estado e três representa forças do Estado no processo formador da dinâmica econômica e social. Há uma evolução progressiva na produção que reflete na sucessão dos representantes nos polos. A tecnologia em desenvolvimento faz com que sempre haja duas forças em disputa, de um lado o modo produtivo vigente, de outro, o modo produtivo inovador. Quando há uma conciliação das forças produtivas, as antigas unidades e coesão da classe dirigente desaparecem. 
Para tanto, a estrutura econômica da dualidade brasileira pode ser organizada segundo Rangel (2005), da seguinte forma:

Quadro 2. Os polos da dualidade econômica brasileira.

\begin{tabular}{|c|l|l|l|l|l|}
\hline \multirow{2}{*}{ Polos } & \multirow{2}{*}{ Lados } & $\begin{array}{c}\mathbf{1}^{\mathbf{a}} \text { dualidade } \\
\mathbf{1 8 1 5 - 1 8 7 3}\end{array}$ & $\begin{array}{l}\mathbf{2}^{\mathbf{a}} \text { dualidade } \\
\mathbf{1 8 7 3 - 1 9 2 2}\end{array}$ & $\begin{array}{l}\mathbf{3}^{\mathbf{a}} \text { dualidade } \\
\mathbf{1 9 2 2 - 1 9 7 3}\end{array}$ & $\begin{array}{l}\mathbf{4}^{\mathbf{a}} \text { dualidade } \\
\mathbf{1 9 7 3 - ?}\end{array}$ \\
\hline \multirow{3}{*}{ Interno } & Interno & Escravismo & Feudalismo & Feudalismo & Semi-salariato \\
\cline { 2 - 6 } & Externo & Feudalismo & $\begin{array}{l}\text { Capitalismo } \\
\text { mercantil }\end{array}$ & $\begin{array}{l}\text { Capitalismo } \\
\text { Mercantil }\end{array}$ & $\begin{array}{l}\text { Semi- } \\
\text { capitalista rural }\end{array}$ \\
\hline \multirow{3}{*}{ Externo } & \multirow{2}{*}{$\begin{array}{l}\text { Interno } \\
\text { Capitalismo } \\
\text { mercantil }\end{array}$} & $\begin{array}{l}\text { Capitalismo } \\
\text { Mercantil }\end{array}$ & $\begin{array}{l}\text { Capitalismo } \\
\text { Industrial }\end{array}$ & $\begin{array}{l}\text { Capitalismo } \\
\text { Industrial }\end{array}$ \\
\cline { 2 - 6 } & Externo & $\begin{array}{l}\text { Capitalismo } \\
\text { Industrial }\end{array}$ & $\begin{array}{l}\text { Capitalismo } \\
\text { Industrial }\end{array}$ & $\begin{array}{l}\text { Capitalismo } \\
\text { Financeiro }\end{array}$ & $\begin{array}{l}\text { Capitalismo } \\
\text { Financeiro }\end{array}$ \\
\hline
\end{tabular}

Fonte: Rangel (2005) organizado pelo autor.

A classe hegemônica sempre será a estruturada no território, o que proporciona liberdade do arranjo produtivo inovador da classe ressurgente fazer testes de sua aplicabilidade e aceitação no mesmo. Neste ponto, a classe que terá uma inovação será a hegemônica, que tem um polo renovado, sendo uma formação social nascente e um polo não renovado, uma classe em plena maturidade.

Na primeira, a inexperiência são marcos presentes no exercício do poder, na segunda, há uma inversão, trata-se de uma classe que tem e que sabe trabalhar com o poder. É a saturação deste que provoca desgaste na hegemonia e proporciona um rearranjo produtivo. "Do ponto de vista de nossa formação periférica, isso importa em queda do volume físico de nossas explorações, em piora dos termos de intercâmbio, em contração da capacidade para importar etc”. (RANGEL, 2005, p.667).

Como forma de melhor explicitar esta formação na região Sudeste da Amazônia Oriental, tendo Palmas como foco da análise, faz-se necessário trabalhar em sua particularidade, relacionando a dualidade econômica brasileira com a dualidade econômica regional. O objetivo principal desta análise é identificar por meio de uma organização histórica a criação de Palmas e seu papel regional.

\section{A PRIMEIRA DUALIDADE DA ECONOMIA}

Para Rangel (2005), o advento da vinda da família Real para o Brasil e a abertura dos portos, deu início a organização do polo externo brasileiro. $\mathrm{O}$ capitalismo mercantil ligado a Portugal, assegurou o modo escravista no país deixado pós-colônia. As fazendas de escravos submetidas a Coroa portuguesa pelas relações de suserania e vassalagem, formaram o sócio maior - vassalos/ senhores de escravos, que no país se sustentava pelo escravismo e na Europa pelo feudalismo. Os representantes do polo externo, do lado interno era formado pelos comerciantes, em sua maioria não brasileiros, com pouca expressão política, formando o sócio menor do poder. Para Pereira (1993), esta dualidade foi caracterizada pelo latifúndio feudal, que não é igual ao latifúndio medieval da Europa ou do asiático, mas, que em sua essência lembra o servo feudal.

Então, a primeira dualidade brasileira teve início em 1822 com a proclamação da independência e terminou em 1889, com a proclamação da República. Este período correspondeu a fase B do Ciclo Longo - Primeiro Kondratiev.

Os modos de produção se complementam e formam a economia nacional. A estrutura econômica é dinâmica, proporcionando uma ruptura e uma substituição do polo mais antigo.

Na primeira dualidade,

o Estado brasileiro em formação teria, pois, a seguinte estrutura: sócio maior (hegemônico): a classe dos barões-senhores de escravos; sócio menor: a classe dos comerciantes (principalmente exportadores - importadores) em estreita ligação com o capitalismo industrial estrangeiro, que constitui o lado externo do pólo externo (RANGEL, 2005, p.670).

Neste ponto, a fazenda de escravo representava o lado saturado da economia e, que se diluía por novas formas produtivas. A mão de obra utilizada nos cafezais teve em seu primeiro momento o excedente de escravos que restaram das áreas auríferas (FURTADO, 2005). Mas, a economia cafeeira possibilitou uma nova classe empresarial, que geograficamente se concentrou na região Sudeste do país. Experiente, empreendedora e conhecedora de seus negócios comerciais colocou a economia do país com condições de financiar a produção cafeeira e alavancar um crescimento no setor. Dessa forma, o país estava estruturado para a segunda dualidade da economia, rompendo com o escravismo e inaugurando o capitalismo mercantil que até então era o sócio menor.

Para Valverde (1985, p.33), todo o crescimento econômico das lavouras do café, veio em decorrência ao trabalho escravo, "o Brasil é o café; o café é o negro”. O número do tráfico de escravos na primeira metade do século XIX foi grande, e mesmo com a promulgação de uma lei em 7 de novembro de 1831 dando liberdade aos escravos que chagassem no país a partir daquela data, de nada valeu, pois as oligarquias que comandava o país na época não acataram. "A escravatura estava fadada ao desaparecimento, mas os fazendeiros de café estavam, geralmente, por demais dependentes dela para que quisessem abrir mão do trabalho escravo" (VALVERDE, 1985, p.35). 
No entanto, a fazenda de café se concentrou no Centro-Sul do país, enquanto o engenho ficou no Nordeste. Para Valverde (1985, p.43), “os fazendeiros de café tornaram uma classe mais rica, mais poderosa e mais refinada que a dos senhores de engenho". No entanto, o alicerce de toda essa produção foi o trabalho escravo.

Com a expansão da economia açucareira, impulsionou a necessidade de aumento da criação de gado. Com a escassez da lenha e com os danos provocados à lavoura, tornou-se necessário encontrar novas áreas para a criação do gado que não fossem litorâneas. Para Furtado (2005), a divisão das duas atividades econômicas: a açucareira e a pecuária, abriu espaço para o surgimento de uma economia dependente na região nordestina. A interiorização da criação de gado foi importante para a ocupação das terras das porções centrais do país. Mas, era uma economia à princípio muito reduzida, não ultrapassando os $5 \%$ do valor da exportação açucareira do Nordeste.

Segundo Furtado (2005), o litoral não possuía também boa qualidade de pastos para abrigar o gado, o que justifica ainda mais a rápida penetração pelo sertão, ultrapassando o rio São Francisco e alcançando o rio Tocantins e daí para o norte: o estado do Maranhão no começo do século XVII. Quanto mais se interiorizava, mais oneroso ficava o transporte deste gado até as regiões litorâneas. Com os lucros caindo, o interesse pela criação de animais também diminuía e, ao mesmo tempo, a relação de trabalho se diversificava entre os meeiros, os indígenas e escravos. Era uma atividade em sua grande parte de subsistência, onde aproveitava tudo do gado para garantir a sobrevivência no sertão. Este modelo econômico acabou modificando a economia nordestina produtora do açúcar, para uma economia de subsistência da pecuária extensiva. Para Valverde (1985, p.163), "foi pelas fazendas de criação que se povoou todo o Piauí e o sul do Maranhão até as barrancas direita do Tocantins".

Para Lira (2007), a plantação da cana no litoral foi uma das principais causa do avanço da pecuária pelo sertão. As frentes nordestinas da pecuária avançaram as barreiras do rio São Francisco e ocuparam o sul do Maranhão no século XVIII. Atravessaram o rio Tocantins no século XIX e ocuparam o norte de Goiás (Tocantins). Posteriormente, avançaram um pouco mais, ultrapassando o rio Araguaia e ocupando o sudeste do Pará.

O tipo de empreendimento feito no Maranhão permitiu que, esgotado os recursos em um local, os investimentos também saíssem do mesmo em busca de explorar uma nova área com potencial de recursos.

No século XVIII foi feito algumas reformas na economia maranhense por Marquês de Pombal, como a Companhia Geral do Grão-Pará e Maranhão. A criação dessa companhia foi importante para a logística no Estado, proporcionando com que este mantivesse uma comercialização com a Europa. Esta forma comercial permitiu introduzir outros tipos de mão de obra que não fosse a indígena, possibilitando que os cultivos do algodão, arroz e a cana-de-açúcar fossem realizados nas terras férteis nas proximidades dos rios.

Para Andrade (1970, p.139), medidas foram necessárias para que esta diversificação econômica maranhense tornassem possível, dentre estas a

introdução de escravos africanos e fornecimento de créditos aos colonos não só aquisição destes como para estabelecimento de campos de cultura, introdução de sementes de arroz e algodão de melhor qualidade a fim de obter um aumento quantitativo e qualitativo da produção; organização de uma criteriosa política de preços para a aquisição dos produtos da terra e venda dos produtos europeus e o estabelecimento de um sistema de navegação para o Reino que permitisse a exportação no tempo oportuno dos produtos da terra.

No entanto, a modernização da economia maranhense teria uma consequência rápida e considerável, elevando o Maranhão a ser uma das áreas mais prósperas da América Portuguesa.

Essa dinâmica econômica regional proporcionou que áreas do sul do estado do Maranhão fossem ocupadas pelos não índios.

A economia pós-século XVIII se expandiu no que se trata a exportação do algodão e do arroz e, posteriormente, pela cana-de-açúcar.

A quantidade de dinheiro que passou a penetrar no Maranhão crescia de ano para ano, de vez que iniciada a exportação do algodão pela Companhia em 1769, com apenas 130 sacas, viu essa quantidade crescer de ano para ano, até atingir 29.799 sacas em 1800 quando era, depois de Pernambuco, o maior exportador de algodão da América Portuguesa. (ANDRADE, 1970, p.142).

Para Furtado (2005), foi com a desorganização do mercado do açúcar na segunda metade do século XVII, que impossibilitou aos colonos do Maranhão dedicar-se a uma atividade que lhes permitisse iniciar um processo de capitalização e desenvolvimento. Ficando este Estado a mercê de uma expansão econômica baseada no extrativismo vegetal, com auxílio do trabalho indígena, diferente dos moldes escravista.

Outra atividade que vale destaque na economia maranhense, foi a produção do couro bovino, representando a terceira riqueza da região depois do algodão e do arroz. Para Andrade (1970, p.142), sua exportação no século XVIII, “subiu de 21.810 peles em 1760, para 31.625 em 1767, decaindo daí em diante ao ponto de resumir-se em 1771 à apenas 11.460 peles”.

A economia do couro proporcionou que as áreas sul-maranhense pudessem ser ocupadas, e também, possibilitou uma comercialização com os estados da 
Bahia, Minas Gerais e Rio de Janeiro. "Na realidade, o Sul era um outro Maranhão pelas suas condições naturais, pelo seu povoamento e pelas atividades econômicas dominantes" (ANDRADE, 1970, p.143), povoado por pessoas que em sua maioria formada por tangedores de gado que transpuseram o rio Parnaíba e ocuparam sua margem esquerda, aproveitando a pastagem boa que o local dispunha para o gado. Esta área mantinha forte vínculo com a Bahia e só mudou esta organização a partir das oficinas de fabricação da carne-seca, que passou a ser transportada em embarcações pelo rio Parnaíba. Porém, "essa indústria seria pouco a pouco liquidada pelas secas periódicas que dizimavam o rebanho nordestino e que terminariam por extingui-la completamente nos últimos anos do século XVIII" (ANDRADE, 1970, p.144).

Os primeiros 50 anos do século XIX foram marcados por uma crise econômica na Colônia/Império, mas, no Maranhão houve um crescimento econômico, que para Furtado (2005) foi local e não teve repercussão no país.

O período correspondente a meados do século XIX, foi marcado por uma crise na economia maranhense. De um lado, a queda dos preços do algodão, principalmente, pela entrada do algodão egípcio de melhor qualidade, por outro lado, a abolição da escravatura no Brasil. Muitos proprietários venderam suas terras e empregaram o dinheiro na aquisição de ações de sociedade anônima, visando a criação de indústrias em São Luís. Estas tiveram vida curta, só algumas sobreviveram aos endividamentos, fatores que se deve a falta de viabilidade no transporte que a região possuía e da existência de uma elite pouco empreendedora. Tratando sobre este assunto, Andrade (1970, p.160) ressalta que, “em pouco mais de século, um Estado, que fora um dos mais ricos do Brasil e que procuravam no Norte competir até com Pernambuco, se viu reduzido a um dos mais pobres e subdesenvolvidos da Federação". Logo após, com as quedas dos preços do algodão, este Estado teve sua produção limitada, reduzida a um complemento à economia de subsistência.

Esta organização possibilitou a formação do sócio menor. O sócio menor se constituía pelos pequenos proprietários de rebanhos que viviam isolados especificamente na porção norte, uma vez que em decorrência da economia açucareira houve uma interiorização desta atividade no sul do Maranhão e no norte de Goiás (Tocantins). Era uma atividade de subsistência, mas, que mantinha uma relação comercial do excedente da produção para os engenhos do Nordeste, por isso denominada de capitalismo mercantil.

Em se tratando sobre a economia mineira, Furtado (2005), afirma que a base desta era o trabalho escravo, mais em moldes diferentes da economia açucareira. Nesta, a forma como se organizava o trabalho permitiu que o escravo tivesse maior iniciativa, muito destes chegaram mesmo a trabalhar por conta própria, comprometendo-se a pagar periodicamente uma quantia fixa ao seu dono, o que abriu a possibilidade de comprar a própria liberdade.

Outra questão que se pode falar é que as relações que se estabeleciam com a terra na mineração eram diferentes da açucareira, pois havia uma instabilidade quanto ao lucro advindo da terra, o garimpo e o lucro, eram incertos.

No ano de 1822 apresentava-se uma crise da economia aurífera, mas, a base social e econômica ainda fundava-se no auge deste período. Pela escassez do ouro, obrigava os antigos mineradores a buscar novas formas de enriquecimento, neste ponto, a pecuária extensiva mostrava-se como uma saída para a crise econômica. A primazia do norte na produção pecuária ocorreu tanto porque a área comportava as vilas mineradoras do século XVIII, como também, porque o centro-norte tinha melhor acesso ao mercado da Bahia. Para Lira (1995, p.110), "a comarca se transformara em região exportadora de gado que leva pelos caminhos do sertão imensas boiadas para serem vendidas na Bahia e na região centro-sul de Goiás".

Em suma, se observar em um contexto regional que mesmo em crise, os antigos mineradores, agora pecuarista, constituíam-se o sócio maior que já se encontrava em crise, mas, mantinha suas áreas de influência de norte à sul da região e principalmente, com a Bahia (PARENTE, 2007). Sua área de concentração maior ainda era o polígono do ouro (sul da região). Mas, não foram os mineradores que se empenharam no movimento separatista do norte da Capitania de Goiás, mais os criadores de gado ligados ao Nordeste, que opuseram ao sul dominado pelos paulistas.

\section{A SEGUNDA DUALIDADE ECONÔMICA}

Se na $1^{\text {a }}$ dualidade os senhores de escravo era o sócio maior e os comerciantes o sócio menor, na $2^{\text {a }}$ dualidade, com a precarização do modo escravista, o capitalismo mercantil passou a ser sócio maior, respaldado sobre o capitalismo industrial no lado externo do polo externo. Neste norte, Rangel (1981) afirma que

a interiorização do aparelho de intermediação mercantil, que fundara a primeira dualidade, (...). colocava esse aparelho, isto é, a classe dos comerciantes, em parte já voltada para o comércio interno, em condição propícia ao progressivo esvaziamento das relações de susserânia/vassalagem que presidiam, na origem, às relações entre o oikos escravista e o resto do mundo, vale dizer, o mercado capitalista. Ao mesmo tempo que o senhor de escravos se convertia (nas relações internas da fazenda) em senhor feudal, o vassalo, que ele também era (nas relações externas da mesma), convertia-se em comerciante. O capitalismo chegava, pois, não mais indireta, mas 
agora diretamente, à fazenda, por onde, no advento da primeira dualidade havia chegado à economia nacional, isto é, pelo lado externo (RANGEL, 1981, p. 23).

Na segunda dualidade brasileira, o "sócio maior: a burguesia comerciante, representativa do plo externo; sócio menor: os fazendeiros, latifundiários feudais, por um lado, e comerciantes, por outro, representando o pólo interno" (RANGEL, 2005, p.674).

Com a Proclamação da República em 1889, o latifúndio feudal teve acesso ao pacto de poder da sociedade brasileira, se estruturando a altura de disputar o poder com o sócio maior que era o capital comercial. "Na década de 20 o latifúndio feudal havia superado todas essas sobrevivências do regime anterior e era uma classe para si, e não apenas uma classe em si” (RANGEL, 1981, p.146).

Com a industrialização da Inglaterra houve uma desagregação do sistema pré-capitalista, impulsionando uma urbanização e um aumento das pessoas ativas para o mercado de trabalho. Em contrapartida, no Brasil com o fim do escravismo, houve uma escassez da mão de obra, o que auxiliou numa expansão das atividades econômicas de norte à sul do país e, na maioria dos casos, voltados para uma agricultura de subsistência que tinha a roça como principal estrutura da produção. A abolição da escravidão no país foi um rompimento com o modo de produção que vinha desde a colonização e que era o pilar de sustentação da velha oligarquia que se consolidou no país.

Apoiada sobre o comércio exterior, a atividade comercial produziu um desenvolvimento econômico estruturando este sistema como o mais dinâmico da época na economia brasileira.

Com a crise econômica, o sócio maior teve a responsabilidade de alavancar a economia por meio de uma diversificação da atividade manufatureira e artesanal. Os fazendeiros mudaram para a cidade e com eles um grande número de escravos, que passaram a ter vida diferente da labuta do campo. Muitos escravos foram incorporados ao trabalho "urbano", alguns antes mesmo de serem libertos pelos seus "proprietários". Não houve uma oposição forte nesta transição de poder, e isso foi causado pela capacidade que surgia nas fazendas para a exportação do café.

Como forma de solucionar o déficit de trabalhadores nas lavouras, buscouse por meio das colonizações europeias. Este processo proporcionou com que na região amazônica houvesse mão de obra para a economia da borracha, principalmente, de nordestinos.

Com a crise na exportação do café e uma organização da mão de obra assalariada no país, produziu procura por novos investimentos. A fazenda de café se constituía de um montante de capital investido em terras e na lavoura, voltado exclusivamente para as exportações. Com o seu declínio, impulsionou a formação de uma nova elite no país.

As transferências de rendas entre os setores de exportação e subsistência beneficiaram de certa forma o setor exportador da economia. Neste setor havia uma transferência de renda advinda do pagamento em moeda para o excedente da produção de subsistência e, da compra de produtos manufaturados produzidos internamente ou exportado. Nas cidades, a economia também mantinha-se pelos salários pagos por estas empresas e relação comercial. Foi a classe média formada pelos assalariados do governo e do comércio que começaram a fazer oposição ao interesse dos grandes capitalistas agrícola-exportadores. Segundo Furtado (2005), a influência deste setor no governo foi substancialmente subtraído, gerando a partir de então uma tensão entre os interesses do governo federal e dos governos estaduais.

Nos anos de 1920, já se presenciava uma forte queda na produção do café, o que anunciava uma nova configuração do poder.

Para Furtado (2005), a economia nordestina estava apoiada sobre dois sistemas: um litorâneo voltado para o comércio de exportação, e outro, mediterrâneo, que mantinha sua direção para a economia de subsistência. Neste período havia uma crise acentuada na economia açucareira, o que empurrava a economia de subsistência para as áreas mais retiradas e pobres, apoiadas sobre a pecuária.

Mas, diferentemente do processo ocorrido no Centro-Sul, na Amazônia, na porção leste da região também chamada de matas do Pará, os nordestinos já chegava devendo nos acampamentos. Devia o transporte até a floresta, a alimentação e utensílios de trabalho, o que provocou com que estes tivessem de complementar sua renda com a caça, pesca e coleta de frutos, um "retorno a forma primitiva de subsistência”.

No sul da região, a pecuária era extensiva e não constituía na formação de riqueza no final do século XIX e início do século XX para a região. Vale ressaltar, que a pecuária nesta porção do território não surgiu pelo engenho, mas, pela mineração que introduziu a atividade. Com a sua decadência, esta se tornou uma atividade de subsistência, mas, que segundo Barbosa (1999) firmava-se no território como uma nova classe que surgia, a dos pecuaristas.

A porção norte da região se integrava a economia maranhense abastecendo os mercados por meio do excedente da agricultura e pecuária, a porção sul ainda vivia sem criar novas alternativas comerciais com o mercado baiano, que fortalecia com a produção do cacau. Para Andrade (1994, p.127), a parte sul da região "foi ocupada por criadores de gado vindos do Vale do São Francisco, que visavam ao 
abastecimento dos mineradores, e por pequenos produtores agrícolas, que faziam uma agricultura de alimentos". Isto mostra que com o declínio da mineração, houve também, um declínio da atividade pecuária e, ainda mais aprofundada com as quedas das importações para a Bahia.

Ao norte, a pecuária tornou-se atividade principal e articulou-se com a economia da borracha e da castanha que entrava em auge econômico. O abastecimento das áreas de exploração vegetal foi importante para o desenvolvimento da pecuária. Estruturada e articulada ao território, a oligarquia formada pela pecuária e agricultura no sul do Maranhão e norte do Tocantins se consolidou como sócio menor. Em contrapartida, o sul mantinha relações importantes com a capital de Goiás e com a oligarquia dos Caiados, que comandava o poder apoiada pelos cafeicultores de São Paulo, mas, empobrecidos não chegava a constituir o sócio menor, antes, este se formou pelo capitalismo mercantil que se estabeleceu ao longo do rio Tocantins e Araguaia sobre o comando de Dianópolis, Porto Nacional, Pedro Afonso, Carolina e Conceição do Araguaia.

\section{A TERCEIRA DUALIDADE ECONÔMICA}

A terceira dualidade iniciou no período pós Primeira Guerra Mundial. Neste período surgiu uma necessidade da classe comerciante internalizar o modo de produção dominante. Esta classe era a sócia maior da $2^{\mathrm{a}}$ dualidade e, estritamente ligada ao capitalismo industrial europeu, representando o lado interno do polo externo. Mas, com a queda do comércio exterior, seguida da subtração da capacidade de importar, pressionava por uma substituição de importações. Rangel (1981) faz a seguinte colocação:

$\mathrm{Na}$ época do advento da terceira dualidade brasileira, o capitalismo financeiro europeu (...) Sua política continuava a se organizar o suprimento de matériasprimas e produtos agro-primários para a metrópole e preservar nosso mercado para os produtos industriais metropolitanos. Outra, porém, seria a atitude do capital financeiro norte-americano, que não era supridor tradicional de produtos industriais no Brasil e contava com uma vasta e diversificada produção metropolitana, condição que o desenvolvimento da técnica só tendia a consolidar, industrializando a agricultura e a produção de matérias-primas. Conseqüentemente, esse novo capital financeiro pouco tinha a perder com o desenvolvimento de alguma indústria no Brasil e, ao contrário, muito tinha a ganhar (RANGEL, 1981, p. 28).

Esta dualidade se organizou pelo feudalismo (lado interno) e capitalismo mercantil (lado externo), formando o polo interno, pelo capitalismo industrial (lado interno) e capitalismo financeiro (lado externo), formando o polo externo.
Neste caso, o pacto de poder era constituído pelos fazendeiros-comerciantes no polo interno, sócio maior. Estes fazendeiros não podem ser identificados apenas como os cafeicultores, mais como os latifundiários substituidores de importações, necessariamente representados pelo latifúndio gaúcho e por latifundiários do Norte/Nordeste do país que se aliaram a burguesia industrial nascente do Sudeste, o sócio menor, representando o polo externo.

Pelo processo de substituição de importações, o pacto para a formação do parque industrial brasileiro é estruturado e proporciona uma nova organização macroeconômica no país.

Parte das indústrias instaladas no país nos anos 30 foram montadas com equipamentos provenientes de fábricas que havia fechado as portas com a recessão de 1929. As indústrias instaladas foram de bens de capital que encontraram um campo fértil para suas ampliações comerciais no Brasil, pois a procura por bens de capital cresceu em meio a precariedades que se encontravam as importações. Este processo fortaleceu a capacidade produtiva interna em detrimento do sistema comercial que se havia instalado no país por meio das importações, nesta feita, se formava um mercado interno que consumia a produção por meio do aumento do poder de compra da população brasileira.

Com a Segunda Guerra Mundial, alguns problemas foram criados, inclusive a dificuldade de importar peças para a manutenção das máquinas. Este processo provocou um fortalecimento do setor externo voltado para a exportação, pois a tensão provocada pela guerra trouxe através dos gastos governamentais, a utilização da capacidade produtiva ociosa.

Por fatores ligados a conjuntura favorável ao mercado interno, aumentou a taxa de capitalização, mesmo em decorrência das pressões sofridas pela variação cambial, a oligarquia industrial fez valer sua hegemonia por meio de um conjunto de políticas de controle cambial e de importações, elevando suas rentabilidades e ampliando as oportunidades de investimento no país por estes empresários.

O sócio maior - latifúndio feudal era dividido segundo seus interesses regionais. Enquanto o latifúndio gaúcho se firmava como substituidor de importações, o latifúndio paulista organizava seu interesse em torno da produção para exportação. Com a crise do café na década de 1930, deprimindo a capacidade do Brasil em importar, criou-se implicitamente a possibilidade de reserva de mercado para todas as atividades substitutivas de importações, tendo o latifúndio gaúcho à frente do processo. O final da Primeira República marcou uma dupla transição econômica que tinha uma economia com regime cambial e comercial livre baseado em uma produção primário-exportadora do café, passando para uma economia que surgia voltada para dentro, com rigidez sobre as transações externas. 
Mas, “em São Paulo, não no Rio Grande do Sul, vinha-se desenvolvendo o outro membro da futura dualidade ou coalizão dominante: o capital industrial" (RANGEL, 1981, p.146). Este nascia voltado para o mercado interno, sem diálogo com o latifúndio paulista, mas, com relações com o latifúndio gaúcho e com a burguesia industrial emergente de São Paulo que passou a patrocinar o poder nascente da industrialização.

Tendo como base o processo de substituição de importações que começou com o governo de Getúlio Vargas, tal processo, iniciou-se assim que o nível de urbanização da sociedade brasileira aumentou. A formação industrial começou com o aproveitamento da mão de obra que antes estava ocupada no campo e que passou a ser utilizada na forma artesanal da produção no setor secundário da economia brasileira. Para Rangel (1981), esta produção se concentrou nos estados do Sudeste e capitais nordestinas e foi necessária para criar salários e, consequentemente, consumidores.

Este processo foi decisivo para criar no país uma autonomia na produção industrial. Partes dos utensílios da produção brasileira continuaram sendo importados, mas, a montagem passou a ser feita no país, criando uma ocupação da mão de obra ociosa que havia.

Em se tratando do Sudeste da Amazônia Oriental, o declínio do extrativismo da borracha, da castanha-do-pará e do ouro rompeu com o sistema de aviação e produziu queda da importância do capital mercantil na região. Não houve uma substituição de produção, antes uma homogeneização desta, ou seja, a economia implantada não foi o capitalismo industrial, mas uma ampliação das atividades agropecuárias.

Para Campos (2004, p.20), “a corrente migratória que demanda a Goiás dirige-se para o campo: entre 1940 e 1950, a população rural goiana cresceu 73,3\%, e a urbana, $26,7 \%$ ". Como a pecuária enfrentava uma crise estrutural, houve uma canalização de recursos para a agricultura, "a pecuária deixa de ser a principal riqueza, e a agricultura, com a produção do arroz, assume o primeiro lugar em importância na renda do estado" (CAMPOS, 2004, p.23). Em se tratando do estado do Tocantins levou-se em consideração que a área ficou a mercê do investimento e teve na pecuária sua base econômica.

Lira (1995) trabalhou com duas forças que nasceu com o movimento de 1930, de um lado os pactos estaduais, organizado pelo latifúndio que queria ter suas terras improdutivas sem preocupação de políticas contrárias, e o pacto federalista, formado pelos coronéis que buscava uma organização mais ampla e que tivesse base no coronelialismo o rompimento do poder dos latifundiários.
Havia dois desenvolvimentos em Goiás, um comandado pelo sul ligado a elite agrária dos Caiados, e outro, um norte isolado, mas, subdividido em dois blocos: o extremo norte e o centro-norte. Neste último, o campo da disputa político-econômica foi fértil para o desenvolvimento do coronelialismo, com hegemonia do poder local, mantendo suas extensões de poder desde Porto Nacional, Dianópolis e Tocantinópolis (LIRA, 1995).

Com a Constituição Federal de 1946, a criação de novos estados passou a ser por meio de votos do legislativo, neste ponto, começou a ter uma luta pela representatividade no legislativo para aprovação de projetos regionais, que para Lira (1995, p.127) pode ter gerado alguns cenários no norte de Goiás quanto a sua luta pela criação do estado do Tocantins:

a) a opção pela corrente estadualista, portanto vinculado aos objetivos oligárquicos da região; b) o campo, jurídico, militar e religioso da luta anterior transferiu se para o campo da "intelectualidade" agrária, tendo em vista que as novas lideranças eram oriundos da oligarquia agrária regional; c) é desprezada outras formas de lutas e faz-se a opção pela luta através da imprensa.

O norte e o sul de Goiás historicamente tiveram conflitos. Mas, vale frisar dentro da história política de Goiás que o latifúndio teve derrota no pacto de poder da terceira dualidade. Este era apoiado pelas oligarquias paulista do café, comandado principalmente pelos Caiados que dominava o cenário políticoeconômico goiano. Mas, pela ampliação do território de suas influências, a coluna mineira deu condições para a instalação da burguesia industrial no poder, comandada por Pedro Ludovico Teixeira.

A construção de Goiânia na década de 30 foi importante para a consolidação do capital industrial em Goiás. A representatividade deste setor na política goiana foi expressiva pelo PTB e PSD. Com a construção de Brasília na década de 50 propiciou a formação de um eixo industrial Goiânia/Anápolis/Brasília.

Mas, o investimento no setor agrícola foi prioridade dos governos de Goiás neste período. A expansão da fronteira agrícola pelo norte de Goiás conduziu a política de infraestrutura, que teve na Belém-Brasília seu marco principal. Esta rodovia trouxe para o Tocantins uma nova organização do território, possibilitando uma expansão da agricultura mecanizada pelas áreas oeste do rio Tocantins. Os corredores das margens dos rios Araguaia e Tocantins não acompanharam a proporção do desenvolvimento que esta rodovia trouxe à pecuária do norte do Tocantins.

Para Loureiro (1992), nos períodos antecedentes a 1960, no predomínio das atividades extrativistas na Amazônia, não propiciou a formação de uma classe média numerosa, não rompendo de imediato com as estrutura polarizada da classe 
dominante com os financiamentos estatais na década de 1960. O investimento em Goiás concentrou-se no setor agrícola da economia, das cinquentas metas inseridas no Plano, nenhuma faz referência à industrialização, e as demais, direta ou indiretamente, têm em vista criar uma infraestrutura necessária ao desenvolvimento do setor agrícola.

A economia do Sudeste da Amazônia Oriental entrou na terceira dualidade com uma instabilidade econômica, o que provocou um ajuste espacial. No entanto, os sócios maior e menor nesta região foi a oligarquia rural, apenas diferenciando-se entre o sócio maior ligado as atividades tradicionais da pecuária e o sócio menor, ligado a expansão da agricultura.

\section{UMA POSSÍVEL QUARTA DUALIDADE}

Com o advento da quarta dualidade brasileira na década de 70, algumas alterações vão ser desencadeadas na região. A consolidação das cidades de Araguaína, Imperatriz e Marabá ao norte, e Gurupi e Palmas ao sul, consolidou os pactos de poder que a partir das alianças regionais se sobressairam. Alguns cuidados têm que ser tomados para tal análise na região, uma vez que haverá uma tendência de continuação das oligarquias no poder, porém, com um processo de substituição. Para início da abordagem, é preferível identificar o que foi a quarta dualidade no Brasil de acordo com Rangel.

A quarta dualidade brasileira teve início com a grande crise mundial do petróleo em 1973, coincidindo com o final da fase expansiva, os trintas anos gloriosos. No Brasil, como mencionado em partes anteriores, o país experimentava um plano de crescimento econômico através do "Milagre Econômico" e, norteava seus investimentos por meio do II PND - 1975/79. O investimento na produção de bens de capital e na tecnifização da agricultura no cerrado foram medidas impactantes para a área central do país.

Houve uma subtração do papel do comércio exterior no montante da renda, mas sua importância esteve atrelada à estratégica organização da formação de capital. Em uma economia agrícola extensiva este processo de formação de capital ocorreu pela incorporação de mão de obra e recursos naturais (FURTADO, 2005). Por outro lado, a construção de estradas, impulsionado principalmente pela interiorização do país (Marcha para o Oeste) proporcionou um investimento em tecnologia para o plantio, transporte rodoviário e infraestrutura.

A área do cerrado central do país e a Amazônia foi um campo propício para receber tais investimentos agrícolas. A monocultura só é compatível com um nível de renda per capita alta e, onde há uma baixa densidade demográfica, pois esta impossibilita a formação superior de organização da produção. A oferta adequada de alimentos unidos a urbanização possibilita a formação de parques industriais, mas, quando a terra se concentra na monocultura, impossibilita a formação de áreas urbanas ou viabiliza mediante a exportação de alimentos e produtos, o que de certa forma, onera a qualidade de vida (FURTADO, 2005).

No final da $3^{\text {a }}$ dualidade o país já tinha consolidado seu parque industrial e impulsionava a industrialização da agricultura, potencializando as contradições do segundo setor da economia (burguesia industrial). A crise do petróleo provocou sérios danos à economia nacional, marcando o início da 4 a dualidade. $\mathrm{O}$ endividamento externo do comércio exterior do país já dava sinal de uma mudança estrutural dentro e fora do Brasil.

A forma como foi estabelecido o parque industrial do país, com elevada razão capital/produto, não permitiu uma reforma de base na estrutura agrária que entrava em choque, alterando ainda mais a crise no sistema. Para Rangel (1981),

com efeito, estivemos industrializando o País com uma estrutura agrária por reformar, e isso somente foi possível pelo motivo (...) de que a execução de projetos industriais (de elevada razão capital/produto), num país de capacidade para importar inelástica e não dispondo ainda de um parque moderno produtor de meios de produção, implicava na produção desses meios por processos pré-industriais, com emprego intensivo de mão-de-obra (métodos artesanais nas atividades de transformação, construção civil rotineira e agricultura muito primitiva, para ganhar alguma receita cambial adicional) (RANGEL, 1981, p. 32).

As terras tornaram-se reservas de valor financeiro e sujeita a sua dinâmica. Com a queda dos valores destas terras, também colocava-se em crise o poder estabelecido pela burguesia rural. A crise mundial teve papel substancial neste processo, proporcionando um novo pacto de poder, organizado pelo sócio maior, a burguesia industrial, e o sócio menor, a burguesia rural ressurgente.

Uma dissidência do velho latifúndio feudal - proprietários capitalistas, por motivos especulativos, de vastas glebas ociosas - procurará desfazer-se de suas terras excedentes, precipitando com isso a queda do preço do fator, o qual, tornando-se acessível, a pequenos adquirentes, destruirá o monopólio latifundiário da terra, sem o qual nenhum feudalismo será possível (RANGEL, 1981, p. 33).

Assim, a $4^{\mathrm{a}}$ dualidade se organizou no polo interno e lado interno, pelo semissalariato e, polo externo e lado interno pelo semicapitalista rural, no polo externo e lado externo, pelo capital financeiro, e pelo lado interno pelo capital industrial. Neste caso, o pacto fundamental do poder ficou constituído pelo sócio maior, a burguesia industrial e o sócio menor a nova burguesia rural 
(empresariados agrícolas). Acabando com todas as possibilidades da formação de uma burguesia feudal.

Desta forma, a quarta dualidade brasileira tem como marco a crise do petróleo de 1973, que correspondeu a fase B do quarto Ciclo de Kondratiev.

No entanto, para Rangel (1981, p.147) “o latifúndio de hoje - todo o latifúndio nacional e não apenas o paulista e o gaúcho - é uma força em desagregação". O processo de industrialização modificou as estruturas no campo, urbanizou a metade da população brasileira e, ainda tecnificou a produção no campo por meio de uma gama de implementos agrícolas, mudando as relações de poder que passou da autoridade sobre a terra, para a capacidade de adquirir e introduzir a tecnologia agrícola sobre a terra.

Mas, ao tratar sobre o Sudeste da Amazônia Oriental, a formação socioespacial vai se distanciar dos estágios da formação social brasileira. Os parques da industrialização terão uma organização muito tenra, ou inexistente tanto em algumas áreas, enquanto em outra, teve uma expansão rápida (Carajás). Por este motivo, não dá para analisar a região como homogênea no quesito economia, ela é muito diversificada nesta porção do território brasileiro.

Até a década de 1990 não se identifica uma sobreposição de sócios no pacto de poder, há uma perpetuação dos poderes oligárquicos agrícola. Para tanto, delimita-se que o sócio maior era constituído pela burguesia rural que tinha na pecuária sua base estruturada e já madura da economia regional.

O sócio menor é formado pela agricultura dos anos de 1970, que se consolidou com grandes projetos, dentre estes o Rio Formoso, o Prodecer III e o projeto de plantio de soja em Balsas.

A configuração das oligarquias em Goiás foi decisiva para delinear as políticas e a organização territorial tocantinense. De tradição agrícola, esta só foi modificada nos anos de 1930 com a construção de Goiânia, "a letargia que dominava na economia goiana só seria quebrada a partir da Revolução de 1930, quando a oligarquia dos Caiados foi apeada do poder e um novo líder, Pedro Ludovico, construiu a cidade de Goiânia para ser a nova capital do estado" (ANDRADE, 1994, p.128). Mas, a burguesia industrial que nascia em Goiás (Goiânia, Anápolis e Brasília) fez um pacto com a oligarquia agrária, o PSD se uniu à UDN e formaram a ARENA que seria a principal sigla partidária. Mais até 1969, não havia representante no executivo e no legislativo em Goiânia, a partir de então, foi colocado no poder Leonino Caiado (ARENA) para prefeito da capital, representando a velha guarda da UDN.

O MDB ficou articulado entre a burguesia industrial e a burguesia do agronegócio, tendo o seu núcleo de apoio as grandes cidades goianas e a cidade de Porto Nacional, principal foco de resguarda do MDB no Norte Goiano. As áreas do extremo norte (Bico do Papagaio e de Araguaína) eram núcleos de apoio à oligarquia conservadora ligada aos Caiados e a ARENA. Tratando sobre esta questão, Borges (2004, p.140), diz que o "MDB aumenta sua bancada através da eleição de políticos com votação principal nas cidades maiores, como Goiânia e Anápolis". Mas, o "norte mantém presença na Assembleia Legislativa por meio da eleição de deputados locais na sigla situacionista”, quer dizer, a ARENA.

Com o desgaste da Ditadura Militar, o MDB ganhou forças e conseguiu votação expressiva no estado. O foco oposicionista da capital e da burguesia industrial e urbana tornou-se marca da política em Goiás. Os votos do norte já não se mostravam tanto situacionista, houve um ligeiro crescimento dos votos oposicionista e, principalmente, sustentado por Porto Nacional. Mais, conforme Borges (2004, p.171)

o PDS mantém a maior parte de seu domínio nas regiões ao norte. Apenas no Bico do Papagaio e no nordeste meridional, o partido governista faz maior número de prefeitos que o PMDB. O extremo oposto se verifica nos municípios da Serra Dourada, Pirineus, Goiânia e Porto Nacional, onde a oposição ganha todos os executivos locais.

Os "vanguardistas" da política conservadora no campo, sustentada pelos Caiados, criou em 1985 a UDR para impedir qualquer proposta inovadora do campo. Foi a concretização do sonho de Ronaldo Caiado em criar um partido voltado para atender a oligarquia tradicional agrária, contrapondo ao movimento de reforma agrária e social no campo. Segundo Barbosa (1999, p.90), esta entidade se alterou tanto para defender seus interesses, que "os associados mais exaltados chegaram a firmar: para cada fazenda invadida, um padre morto". E a questão mais séria é que validaram o que falaram, um exemplo foi a morte do Padre Josino.

Estes ruralistas invadiram os cargos do legislativo de Goiás e passaram a defender a criação do estado do Tocantins como uma necessidade de manutenção no poder, uma vez que ia aumentar a bancada ruralista na Câmara e no Senado Federal, já que se criava um estado totalmente dominado pela UDR.

Mas, apesar das relações de poder ultrapassarem as fronteiras estaduais como já ficou explícito no trabalho, aqui precisa focar um pouco mais sobre a formação do estado do Tocantins para conseguir discutir o processo de formação e criação da cidade de Palmas.

O sonho separatista começou com a pecuária no século XIX e se concretizou com a participação decisiva desse seguimento produtivo. Não que foi o único ou mais importante, o estado foi criado por um conjunto de ações de indivíduos que se dispôs a lutar pela separação da porção norte de Goiás (estudantes, pecuaristas, agricultores, comerciantes, etc). 


\section{Para Lira (1995, p.137),}

esse período compreende a década de setenta e oitenta. É bom observar que justamente no meio do regime militar. É um período em que a elite agrária conservadora assume o comando da luta "separatista" do norte goiano, tendo como campo de batalha, incoerentemente, o próprio sul do Estado.

Em 1974 o deputado Siqueira Campos apresentou um projeto federalista de divisão do estado de Goiás, o que para Lira (1995), pode ter agradado o governo militar. Na década de 80 foi criada a CONORTE - Comissão dos Problemas do Norte Goiano, formada por burocratas que tinha suas atividades nas cidades de Brasília e Goiânia. Para Lira (1995, p.144) afirma que esta tinha o obejtivo de

"desenvolver" o norte goiano, sem tocar na estrutura social, permanecendo intacto o sistema de política agrária, o latifúndio familiar, e os feudos agrários com seus mandantes políticos enraizados em cada uma das cidades do Norte Goiano. A CONORTE buscava a permanência desse sistema político-econômico, arcaico, mendigando entre os políticos sulistas cargos públicos (Secretaria de Governo) para seus (pseudo intelectuais) filiados, com o objetivo de montar um governo paralelo do norte goiano com sede nas cidades de Goiânia e Brasília.

Segundo Lira (1995), esta entidade teve papel importatíssimo na consolidação do Tocantins, mas, não conseguiu se inserir na sociedade, daí sua crítica à entidade.

Siqueira Campos chegou em Colinas junto com os fazendeiros do Paraná, São Paulo, Minas Gerais e sul de Goiás atraídos por terras baratas. Veio com intuito de se tornar fazendeiro no município. Foi eleito em 1965 para deputado federal pela ARENA.

\section{Segundo Lira (1995, p.170),}

é bom lembrar que essas regiões sofrem migrações de fazendeiros do sul, que praticam ali uma agricultura mecanizada, mas em fazendas isoladas e com empréstimos individuais em bancos estatais e privados. A colônia gaúcha na região de Gurupi visível através da CTG é um exemplo do processo de modernização agrícola sendo que a maioria desses agricultores gaúchos estão integrando Projeto do Rio Formoso.

Ainda segundo Barbosa (1999), estes pecuaristas vindo do sul constituíam o novo grupo que passava à disputar a antiga hegemonia de aviadores e fazendeiros tradicionais, disputando cargos no excutivo e legislativos ou até fazendo aliança. Mas,

diferente de Mato Grosso e Mato Grosso do Sul, a "Amazônia Tocantinense" não assistiu a invasão neo-capitalista no campo. As empresas agroindustriais ou agrominerais não se estabeleceram na região com uma intensidade, que pudesse interferir no modelo de ocupação. Pelo contrário, as poucas que se instalaram mantiveram ou reproduziram o modelo colonial das sesmarias, transformados em latifúndios e cristalizado pelo poder político do coronel, reproduzido nas "novas" alianças das oligarquias regionais. Hoje "bem" representadas na UDR (LIRA, 1995, p.173).

Duas áreas passaram a ser estratégicas no Tocantins, uma comandada pela velha oligarquia agrária (porção norte) e, outra, pela agricultura mecanizada (vale do Araguaia). No entanto,

a Belém-Brasilia formou uma região diferenciada economicamente do contexto regional, uma faixa de terra com "modernização" na agricultura e com formação de pastagens e engorda de gado confinado. O trecho de Alvorada a Guaraí, é composto de grandes fazendas criadoras de gado. Essa faixa de terra compõe uma região de expropriação da força de trabalho do camponês e aglutinadora de ampliação do capital privatizado, conseguido através dos empréstimos bancários, públicos e/ou privados e pela renda da terra. (LIRA, 1995, p.196)

Desta forma, no ano de 1988 tem-se o seguinte cenário político-econômico na região, o sócio maior comandado pela cidade de Araguaína que articulava o poder sobre o norte da região, na hegemonia da produção pecuarista. Há uma concentração da criação de gado no município e na região norte do Tocantins, em detrimento ao sul. Com mais de $90 \%$ de toda arrecadação(pecuária) do Estado em 1989, e tendo uma base consolidada que já vinha desde a construção da BR 153, esta é a região com maior poder econômico e político do estado do Tocantins.

O sócio menor que despontava com grande êxito no sul do estado do Tocantins, não disputava sua força com duas cidades (Marabá e Imperatriz) como Araguaína, antes, tinha uma proximidade comercial com a capital de Goiás, Goiânia, que para Borges (2004), a construção desta capital rompeu com as estruturas de elites em Goiás, gerando novo polo econômico e de vida urbana.

A elite da agricultura inicialmente parecida a uma organização social, não passava de um empresariado agrícola nascente. Para Barbosa (1996, p.114) "tendo em vista a formação de cooperativas, no Projeto Rio Formoso estas se assemelhavam mais a empresa capitalistas ou sociedade anônima que de fato a cooperativa". A forma de implantação proporcionou um enriquecimento e a formação de pessoas abastadas e com influência política.

A concentração da produção de grãos no estado do Tocantins deu-se na região de Gurupi.. Com mais de $73 \%$ de toda a arrecadação estadual no setor, se consolidou como o principal centro econômico da agricultura no Estado, disputando força hegemônica com a cidade de Araguaína ao norte. 


\section{PARA CONCLUIR: A CRIAÇÃO DE PALMAS}

Depois de percorrer por uma análise sobre uma possível dualidade criada no estado do Tocantins, conclui-se o trabalho tecendo algumas leituras possíveis deste pacto na criação de Palmas.

A força exercida pelos centros começaram a entrar em evidência no ato da criação do estado do Tocantins pela Constituição Federal do Brasil, em 5 de outubro de 1988. Qual cidade abrigaria a capital? Os centros de poder entraram em cena, os sócios se colocaram na disputa pelas suas influências e buscando ampliar esta área de domínio.

Para Brito (2005, p.40), tratou-a da seguinte forma:

$1^{\circ}$ - Araguaína. Área rica pela pecuária, mas, conflituosa devido a mineração e garimpo, a posse da terra e, também devido à disputa que mantinha pela influência do sul do Maranhão.

$2^{\circ}$ - Gurupi. Localizado ao sul do estado do Tocantins mantinha fortes relações com o estado de Goiás.

Nesta disputa, entra em jogo a cidade de Porto Nacional que segundo Lira (1995, p.222 e 223),

ao contrário de Araguaína e Gurupi, que concentravam suas campanhas para sediar a capital através da força econômica e da mídia, Porto Nacional buscou o caminho popular para sua luta pela capital. Os jornais da época, segundo o $\mathrm{Sr}$ Joaquim Medrado de Souza, então presidente da Associação Comercial de Porto Nacional, davam para Araguaína 85\%, para Gurupi 10\% e para Porto Nacional $5 \%$ de chances para sediar a capital provisória do novo estado do Tocantins (...), quando eles floriam os elogios para Araguaína, não dava a devida importância a Gurupi e rotulam Porto Nacional, também tem tradição na luta popular, talvez adquirida na própria luta pela criação do estado do Tocantins.

A partir desta análise, entra em evidência outro elemento, a influência política. Se comparada a arrecadação de ICMS de Porto Nacional em 1989, verificava-se que era muito pequena em relação aos dois centros maiores, menos de $5 \%$ da receita do Estado.

Mas, desprezar qualquer cidade desta seria conflituoso, pois provocaria uma fragmentação das alianças regionais e de uma possível conciliação política em torno de um objetivo que era a construção de um estado forte e consolidado. Para manter intacta a união que se havia criado com a formação do Tocantins, qualquer cidade que fosse atendida provocaria uma fragmentação desta unidade política.

Porto Nacional, pelo seu movimento social tinha sua afirmação política e representava o maior núcleo de resistência de esquerda em Goiás, que para Borges
(2004, p.171), tratando sobre a oposição ao PMDB nas eleições de 1982, afirma que "a região de Porto Nacional oferece os maiores percentuais oposicionista do norte, em todos os cargos em disputa".

Para Brito (2007), havia uma possibilidade de ser implantada em qualquer uma das três cidades, quando a notícia surpreendeu que a capital seria criada em algumas fazendas no município de Porto Nacional, e que, uma cidade sem prestígio político e nem estrutura econômica iria abrigar por um ano a capital, Miracema do Norte (do Tocantins). Esta estratégia mantinha consolidadas as bases do poder estadual, pois não atenderia nenhum dos núcleos de poder interessados.

Ser a capital, era concentrar volumosos investimentos em infraestrutura logística, assim como, fortalecer a cidade em detrimento do restante do território.

Para Raffestin (1993, p.191), o nascimento de uma capital é um fato sóciopolítico, "nasce ao mesmo tempo da subida de um poder e do desaparecimento de um outro". Há uma força compartimentada sobre a região, as relações de poder orientam-se de forma diferente no território, a medida que há uma relação centralidade-marginalidade, pois, se ela centraliza o poder político, logicamente, ela marginaliza seu entorno. "A centralidade pode ser política, econômica e cultural, mas também pode ser só política, só econômica ou apenas cultural” (RAFFESTIN, 1993, p.193).

Diferentemente de Brasília, criada apenas para abrigar o poder político (VESENTINI, 1986), Palmas foi criada como cidade Geopolítica (LIRA, 1995) e também, como capital econômica (BRITO, 2005). De acordo com Tocantins É (1990, p.1), "Palmas, a capital do Estado do Tocantins, tem seu objetivo empresarial. Com toda uma projeção arquitetônica prevendo a expansão de indústrias. Palmas, a mais nova capital brasileira, hoje é o grande centro de atração de investidores".

A desfragmentação do poder no Tocantins não impediu a formação de oposição política ao governo, mas, criou envolto sobre uma coligação chamada de "União do Tocantins" que, inicialmente sofreu derrotas, mas ocupou o poder por um bom tempo no estado. Para Barbosa (1999), a grande coligação colocou em uma sigla quase todos os partidos políticos do então norte de Goiás, não se tinha mais o PC do B fazendo oposição ao PFL, PSDB ou mesmo, o PSD, todos eles estavam envoltos sobre o discurso de novos tempos no Tocantins. Mas, havia uma oposição formada pelo PMDB e, que tinha seu foco de resistência, no centro do Estado.

O primeiro governo do Tocantins foi formado por dois representantes do norte do estado, os pecuaristas Siqueira Campos (Governador) e Darci Coelho (Vice-Governador). No Senado, havia Antonio Luiz Maia, representante de Porto Nacional, que formava o coro juntamente com Moisés Avelino, Ary Valadão, 
Eduardo Siqueira, Antonio Jorge, Paulo Mourão na Câmara e, na Assembleia Legislativa, representando a área central, mas ligados, de alguma forma, à burguesia agrária.

Três áreas básicas disputavam a influência no estado do Tocantins: uma comandada pelo Norte - Araguaína, outra ao sul - Gurupi, e uma central, na liderança de Palmas, Paraíso e Porto Nacional. Mas, as bancadas se diversificam entre a ruralista comandada pelos parlamentares do norte e do sul, e a base do desenvolvimento industrial, encampado pelos representantes de Palmas.

Os esforços de um novo tempo, desde o primeiro momento da construção foram concentrados em torno de Palmas como o princípio de toda a esperança (Do Sol que gira o Tempo - aos Girassóis o Espaço) do desenvolvimento - industrial, comercial, de ampla infraestrutura, etc. De acordo com o discurso na implantação de Palmas isto é visto com mais nitidez.

Até agora os caminhos foram quase intransponíveis obstáculos, tantos foram aqueles que não chegaram, que inacreditável parecia o termino da jornada, com archote de seu espírito, os ancestrais formaram a grande retaguarda para iluminá-lo e, no inverno e no verão, nas noites, nos dias e nas tempestades, permaneceram incólumes na posteridade a indica-nos a hora de hoje. Chamo-os e sei que me escutam: é a imagem dos que iniciaram a história; são os vultos majestosos do Ouvidor Geral e Presidente do Governo Revolucionário da Comarca de Palma, o patriarca Joaquim Teotônio Segurado e de seus históricos companheiros. São eles que ora se levantam e, ombro a ombro conosco, confraternizam neste momento que sempre viverá no coração de todos, que sempre viverá no orgulho de cada tocantinense e será transmitido às gerações que verão, testemunho de determinação, de esperança e fé (...). Estamos no limiar de uma das maiores obras urbanísticas atuais. A exemplo dos empreendimentos gigantescos que marcaram os tempos, de Goiânia e Brasília, somos aqueles aos quais a providência nos legou a responsabilidade de erguer numa região, ontem deserta, uma cidade moderna e viva, com personalidade própria e arrojada arquitetura (...). E, situada nos umbrais da Amazônia, representará um campo de treinamento, de adaptação do homem brasileiro para seu domínio ordenado e racional (...). Eis a capital do Tocantins, que hoje transferimos para esta cidade de Palmas, pela vontade do povo, pela firme decisão dos poderes constituídos do Estado, e sob as bênçãos de Deus (...). As cidades nascem de um mistério insondável. $\mathrm{E}$ a história falará da dedicação que devotamos a Palmas, para que, parte do universo das transmutações das espécies, possamos ser amanhã nesta terra dadivosa que dará flores e frutos, que purificarão o ar e a água, as noites e os dias, um símbolo de amor à cidade que agora edificamos. (DEZOITO DE MARÇO, 1998, p.05).

Com a derrota da UT para o PMDB no primeiro governo, trouxe a tona que não era consenso de todos a criação de Palmas, havia focos de resistência, e um deles era o PMDB que agora era governo. Com o fim do mandato de Moisés Avelino, a cidade novamente foi exaltada como a grande saída do atraso que o
Estado estava mergulhado. A industrialização era uma propaganda rotineira para viabilizar o "progresso e um novo tempo de esperança".

Mesmo com toda a propaganda sobre Palmas, o grande número de eleitores de Palmas, ofereceu resistência à eleição de Siqueira Campos. Nas eleições de 1998 ao governo do Estado, deu apenas 9,7\% dos votos de vantagem à Siqueira Campos sobre seu adversário. Nas eleições de 2006, foi o principal colégio eleitoral responsável pela derrota de Siqueira Campos. Mas, essa eleição foi apenas um cabo de força entre os latifundiários, pois o governador eleito é um pecuarista representante fiel de Araguaína, apoiado pelos representantes da UDR de Gurupi.

A elite formada por Palmas ainda não se consolidou no poder. Tem no Partido dos Trabalhadores sua principal base política, apesar de ser também formado por pecuaristas. Isso mostra que o sócio maior, oligarquia agrária (do Norte) ainda possui forças para determinar os rumos da política tocantinense.

Mais diante de toda esta disputa pelo poder, Palmas é uma cidade da conciliação, onde os sócios colocam na arena suas forças e se asseguram pela dinâmica que a cidade impõem. Barbosa (1999) chamou a cidade de ilha, que atraiu todo o desenvolvimento para si e esqueceu do restante do estado. Mas, vale ressaltar que por mais que Palmas viesse como uma proposta de industrialização, a oligarquia que comanda o Tocantins é agrária, tendo o sócio maior - os conservadores, concentrados no norte do estado, e o sócio menor - os empresários agrícolas inovadores, concentrados ao sul/centro do estado, que tem na agricultura seu principal monopólio.

A conciliação e o objetivo de construir a capital produziu dinâmicas econômicas não apenas no Tocantins, mais em todo Sudeste da Amazônia Oriental.

\section{REFERÊNCIAS}

ANDRADE, M. C. de. Nordeste, Espaço e Tempo. Petrópolis: Vozes, 1970. (Coleção: Caminhos Brasileiros, 5)

Modernização e pobreza: a expansão da agroindústria canavieira e seu impacto ecológico e social. São Paulo: EUEP, 1994.

APOLINÁRIO, J. R. Vivências escravistas no norte de Goiás no século XVIII. In: GIRALDIN, O. (Org.). A (trans)formação histórica do Tocantins. 2.ed. Goiânia: Ed. UFG, 2004. 
AQUINO, N. A. A construção da Belém-Brasília e a modernidade no Tocantins. Goiânia. 1996. Dissertação (Mestrado em História) - Universidade Federal de Goiás, Goiânia, 1996.

A construção da Belém-Brasília e suas implicações no processo de urbanização do estado do Tocantins. In: GIRALDIN, O. (Org.). A (trans) formação histórica do Tocantins. 2.ed. Goiânia: Ed. UFG, 2004.

Tocantins: cidades e urbanismo em três modelos históricos. In: ENCONTRO DA ASSOCIAÇÃO NACIONAL DE PÓS GRADUAÇÃO E PESQUISA EM AMBIENTE E SOCIEDADES, 3. 2006, Brasília. Anais... Brasília: ANPPAS, 2006.

BARBOSA, Y. M. Conflitos sociais na fronteira amazônica: Projeto Rio Formoso. Campinas: Papirus, 1996.

As políticas territoriais e a criação do estado do Tocantins. 1999. Tese (Doutorado) - Universidade de São Paulo, Faculdade de Filosofia, Letras e Ciências Humanas, São Paulo, 1999.

BECKER, B. K. Geopolítica da Amazônia: A Nova Fronteira de Recursos. Rio de Janeiro: Zahar, 1982.

—. Amazônia. São Paulo: Ática, 1990.

Fragmentação do espaço e formação de regiões na Amazônia - um poder territorial?. In: Revista Brasileira de Geografia,Rio de Janeiro, v.52, n. 4, out./dez. 1990.

. Modernidade e integração do território no Brasil: da integração nacional a integração competitiva. In: Espaço \& Debates, São Paulo, n. 32, ano. 11, 1991.

Amazônia - Geopolítica na Virada do III Milênio. Rio de Janeiro: Editora Garamond, 2004. v. 1.

Dinâmica Urbana na Amazônia. In: DINIZ, C. C.; LEMOS, M. B. (Org.). Economia e Território. Belo Horizonte: CEDEPLAR, 2005.

. Amazônia: geopolítica na virada do III milênio. Rio de Janeiro: GARAMOND, 2007.

BEZERRA, M. S. Palmas, Processo de Implantação da Capital do Tocantins, 1989-1991. 1999. Monografia (Especialização) - UNITINS, Palmas, 1999.
BOGES, P. C. A. O Bipartidarismo autoritário em Goiás. In: SOUZA, D. B. (Org.). Goiás: Sociedade e Estado. Goiânia: Cânone Editorial, 2004a.

. Formação e representações do estado de Goiás. In: SOUZA, D. B. (Org.). Goiás: Sociedade e Estado. Goiânia: Cânone Editorial, 2004b.

BRITO, E. P. de. O Processo de Ocupação do Espaço Urbano: A partir de um olhar em Palmas. In: VI CONGRESSO BRASILEIRO DE GEÓGRAFOS, 6. 2004, Goiânia . Anais... Goiânia: UFG, 2004. Cd-Rom.

Estudos de ocupação do espaço urbano de Palmas. Relatório de Estágio. Palmas: Instituto de Planejamento Urbano de Palmas, 2004.

. Produção e Reprodução do Espaço Urbano de Palmas, Tocantins. Palmas, 2005. Monografia (Bacharelado em Geografia - Universidade Federal do Tocantins, Palmas, 2005.

Reprodução espacial da última cidade planejada na Amazônia brasileira do século XX, Palmas Tocantins. In: ENGETO, 7. 2006. Araguaína. Anais... Araguaína: UFT. 2006. Cd-Rom.

- A importância do Centro Comercial Wilson Vaz na formação do centro urbano de Palmas. In: ENCONTRO REGIONAL DE GEOGRAFIA, 2. 2006, Dourados. Anais... Dourados, 2006.

. Planejamento, especulação imobiliária e vazios urbanos na última cidade planejada do Brasil no século XX. In: ENCONTRO DE GEÓGRAFOS DE AMÉRICA LATINA, 11. 2007, Bogotá. Anais... Bogotá, 2007a.

O planejamento urbano e a formação de uma área central em Palmas Tocantins. In: SEMANA DE GEOGRAFIA DA UNIVERSIDADE ESTADUAL DE LONDRINA, 23; SEMINÁRIO TEMÁTICO DE GEOGRAFIA DO NORTE DO PARANÁ, 2. 2007, Londrina. Anais... Londrina, 2007b.

. A ocupação e os vazios urbanos na cidade de Palmas. In: ENCONTRO NACIONAL DA ANPEGE, 7. 2007, Niterói-RJ. Anais... Niterói, 2007c.

. Uma decisão, um projeto, um sonho e discursos na criação e consolidação de Palmas. In: ENCONTRO NACIONAL DE GEÓGRAFOS, 15. 2008, São Paulo. Anais... São Paulo, 2008.

CAMPOS, F. I. A política tradicional em Goiás: 1930 a 1960. In: SOUZA, D. B. (Org.). Goiás: Sociedade e Estado. Goiânia: Cânone Editorial, 2004. 
CANO, W. Desequilíbrios regionais e concentração industrial no Brasil 1930-1970. São Paulo: Global, 1985.

CARVALHO, F. L. Fronteira e conquistas pelo Araguaia - século XIX. Goiânia: Kelps, 2006.

CORRÊA, R. L. A rede urbana. São Paulo: Ática, 1989.

. Identificação dos centros de gestão do território no Brasil. Rio de Janeiro, 1994. Mimeografado.

Trajetória Geográfica. Rio de Janeiro: Bertrand Brasil, 1997.

CASTRO, N. Expansão rodoviária e desenvolvimento agrícola dos cerrados. In: HELFAND, S.; REZENDE, G. (Org.). Região e Espaço no Desenvolvimento Agrícola Brasileiro. Rio de Janeiro: IPEA, 2003.

CUNHA, M. P. da. Migração no Centro-Oeste Brasileiro: as tendências e características do período de 1986/96. In: HAGAN, D. J. (Org.). Migração e ambiente no Centro-Oeste. Campinas: UNICAMP/Núcleo de Estudos de População; Pronex, 2002.

DEZOITO DE MARÇO. Jornal - Documento. Ano 10 do estado do Tocantins. Palmas, n. 5. 20 maio. 1998.

Ano 10 do estado do Tocantins. Palmas, n. 8, 30 jun. 1998.

FURTADO, C. Formação Econômica do Brasil. 32. ed., São Paulo: Cia. Editora Nacional, 2005.

GASPAR, J. G. Araguaína e sua região: saúde como reforço da polarização. 2002. Dissertação (Mestrado em Geografia) - Universidade Federal de Pernambuco, Recife, 2002.

GOMES, H. Geografia sócio-econômica de Goiás. São Paulo: Livraria Brasil Central, 1969.

; NETO, A. T. Geografia Goiás/Tocantins. Goiânia: Ed. UFG, 1993.

; NETO, A. T.; BARBOSA, A. S. Geografia: Goiás/Tocantins. 2.ed. Rev. Ampl. Goiânia: Ed UFG, 2005.

GOTTIDIENER, M. A produção social do espaço urbano. São Paulo: EDUSP, 1993.
HALL, A. L. Amazônia: desenvolvimento e conflito social no Programa Grande Carajás. Tradução de Ruy Jungmann. Rio de Janeiro: Zahar, 1991.

LEFEBVRE, H. La production de l'espace. Paris: Maspero, 1974.

De lo rural a lo urbano. 3.ed. Barcelona: [s.n.], 1975.

LIRA, E. R. A frente pastoril e a (des)organização dos territórios indígenas no sul do Maranhão e no antigo norte de Goiás. Revista Plurais, Anápolis, v. 1, n. 4, 2006. Disponível em: <http://www.nee.ueg.br>. Acesso em: 24 nov. 2008.

. A Gênese de Palmas-TO. 1995. Dissertação (Mestrado) - Universidade Estadual de São Paulo/UNESP, Presidente Prudente, 1995.

LOUREIRO, V. R. A história social e econômica da Amazônia. In: Estudos e problemas amazônicos: história social e econômica e temas especiais. 2. Ed. Belém: Secretaria de Estado de Educação; CEJUP, 1992.

MANZANO, H. L.; MANZANO, E . Nas barrancas do Tocantins: memórias de um casal de médicos. Goiânia: América, 2005.

OLIVEIRA, A. U. de. Integrar para não entregar: políticas públicas e Amazônia. Campinas: Papirus, 1988. (Série Educando)

OLIVEIRA, F. de. Elegia para uma re(li)gião. 3. ed. Rio de Janeiro: Paz e Terra, 1981.

PARENTE, T. G. O ouro como fonte de atraso. In: GIRALDIN, O. (Org.). A (trans)formação histórica do Tocantins. 2.ed. Goiânia: Ed. UFG, 2002. p. 171-182.

Fundamentos Históricos do Estado do Tocantins. 3.ed. Goiânia: Ed. UFG, 2007.

PEREIRA, L. C. B.; REGO, J. M. Um mestre da economia brasileira: Ignácio Rangel. Revista de Economia Política. São Paulo, v. 13, n. 2, abr./jun. 1993.

PICOLI, F. O capital e a devastação da Amazônia. São Paulo: Expressão Popular, 2006.

RAFFESTINI, C. Por uma Geografia do Poder. São Paulo: Ática, 1993.

RANGEL, I. História da dualidade brasileira. Revista de Economia Política, São Paulo, out./dez. 1981. 
RANGEL, I. Economia: milagre e anti-milagre. Rio de Janeiro: Zahar, 1986.

Obras Reunidas. v. 1-2. São Paulo; Rio de Janeiro: Contraponto, 2005.

RIBEIRO, M. A. C. Amazônia: a dimensão do urbano e a qualidade ambiental. Rio de Jeneiro: IBGE/DEGEO, 1994. Mimeografado.

A complexidade da Rede Urbana Amazônica: três dimensões de análise. Tomo I. Rio de Janeiro, 1998 (Tese apresentada na UFRJ).

A complexidade da Rede Urbana Amazônica: três dimensões de análise. Tomo II. Rio de Janeiro, 1998. (Tese apresentada na UFRJ)

ROCHERFORT, M. A organização urbana da Amazônia Média. Boletim Carioca de Geografia, Rio de Janeiro, 1959.

Problema de organização do espaço urbano.Caderno Prudentino de Geografia, Presidente Prudente, v. 1, n. 1, 1981.

Redes e sistemas. Ensinando sobre o urbano e a região. Tradução de Antônio de Pádua Danesi. São Paulo: Hucitec, 1998.

SANTOS, M. A Natureza do espaço: técnica e tempo/razão e emoção. São Paulo: HUCITEC, 1996.

Técnica, Espaço, Tempo. Globalização e Meio Técnico-CientifícoInformacional. 4. ed. São Paulo: HUCITEC, 1998.

Economia Espacial: Críticas e Alternativas. Tradução de Maria Irene de Q. F. Szmarecsányi. 2. ed. São Paulo: EDUSP, 2003. (Coleção Milton Santos).

Da Totalidade ao Lugar. São Paulo: EDUSP, 2005. (Coleção Milton Santos).

VALVERDE, O. Estudos de Geografia Agrária Brasileira. Petrópolis: Vozes, 1985.

Estudos de Geografia Agrária Brasileira. Petrópolis: Vozes, 1985.

; DIAS, C. V. A rodovia Belém-Brasília: estudo de Geografia Regional.

Rio de Janeiro: Fundação Instituto Brasileiro de Geografia, 1967.

VESENTINI, J. W. A capital da geopolítica. São Paulo: Ática, 1986.

VICENTINI, Y. Cidade e História na Amazônia. Curitiba: Ed. UFPR, 2004.

Texto submetido à Revista em 18.6.2010

Aceito para publicação em 22.7.2010 